- Short Communication

\title{
ASSOCIATION OF PESTALOTIOPSIS GUEPINII (DESM.) STAY. WITH BIPOLARIS LEAF BLIGHT (BpLB) INFECTED WHEAT LEAVES - A NEW RECORD
}

\author{
SHAMIM SHAMSI* AND MST. SELINA MOMTAZ \\ Department of Botany, University of Dhaka, Dhaka-1000, Bangladesh
}

\begin{abstract}
Pestalotiopsis guepinii (Desm.) Stay an anamorphic fungus belonging to the class Celomycetes was isolated from Bipolaris leaf blight (BpLB) infected wheat leaf of two wheat varieties namely, Balaka and Saurab during the period of February to March, 2011. Association of Pestalotiopsis guepinii with wheat is a new record.
\end{abstract}

Key words : Association, Pestalotiopsis guepinii, Wheat varieties

Wheat (Triticum aestivum L.) is considered as the second most staple food crop next to rice in Bangladesh. The average yield of wheat in Bangladesh is lower in comparison to other countries. According to DAE (Directorate of Agricultural Extension) during 2008-09, total wheat production was 849 thousand tons from 395 thousand hectares of land. Diseases play an important role in lowering wheat yield in the country. Wheat is attacked by at least 20 different diseases in Bangladesh (Talukdar 1974, Ahmed 1986), of which five are considered as major diseases, they are Bipolaris leaf blight-BpLB (Bipolaris sorokiniana), leaf rust (Puccinia recondita), seedling blight (Bipolaris sorokiniana), foot and root rot (Sclerotium rolfsii Tode) and black point (B. sorokiniana, Alternaria alternata (Fr) Keissler, Curvularia lunata (Wakker) Boedijn and a species of Fusarium Link.

BpLB or spot blotch caused by Bipolaris sorokiniana (Sacc.) Shoem. (syn Helminthosporium sativum PK \& B; teliomorph: Cochliobolus sativus Ito \& Kurib; Drechslera sorokiniana Drechs ex Dastur) has become the most destructive disease of wheat in the rice-wheat cropping system in Bangladesh. The disease is of serious concern to wheat growers and researchers not only in Bangladesh but also in tropical and subtropical countries of the world. In Bangladesh, the disease occurs in almost all wheat growing areas with varying degrees of severity, causing substantial loss in yield and seed quality (Rashid et al.1994, Alam et al. 1995). The occurrence and severity of the disease are being increasing every year in Bangladesh (Alam et al. 1993).

\footnotetext{
* Corresponding author: <prof.shamsi@gmail.com>.
} 
The present study is based on infected wheat leaves of two wheat varieties, namely Balaka and Saurab collected from Wheat Research Centre, Dinajpur. The fungus was isolated from Bipolaris leaf blight (BpLB) infected wheat plants. Samples were collected during grain filling stage and placed in clean brown paper bags labeled properly and preserved at $4^{\circ} \mathrm{C}$ in refrigerator for subsequent studies.
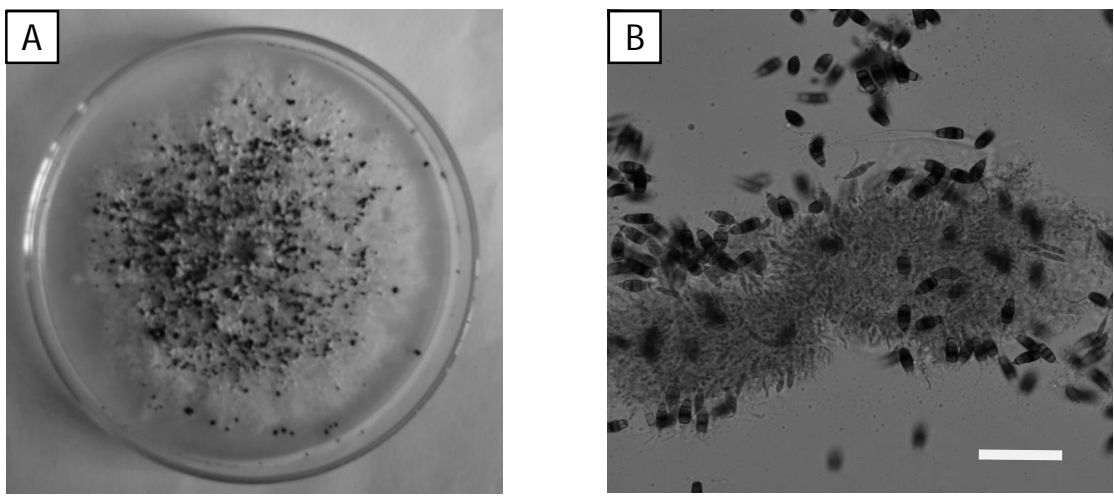

Fig. 1. Pestalotiopsis guepinii : A. Colony on PDA medium. B. Acervuli with conidiophores and conidia. (Bar $=50 \mu \mathrm{m})$.

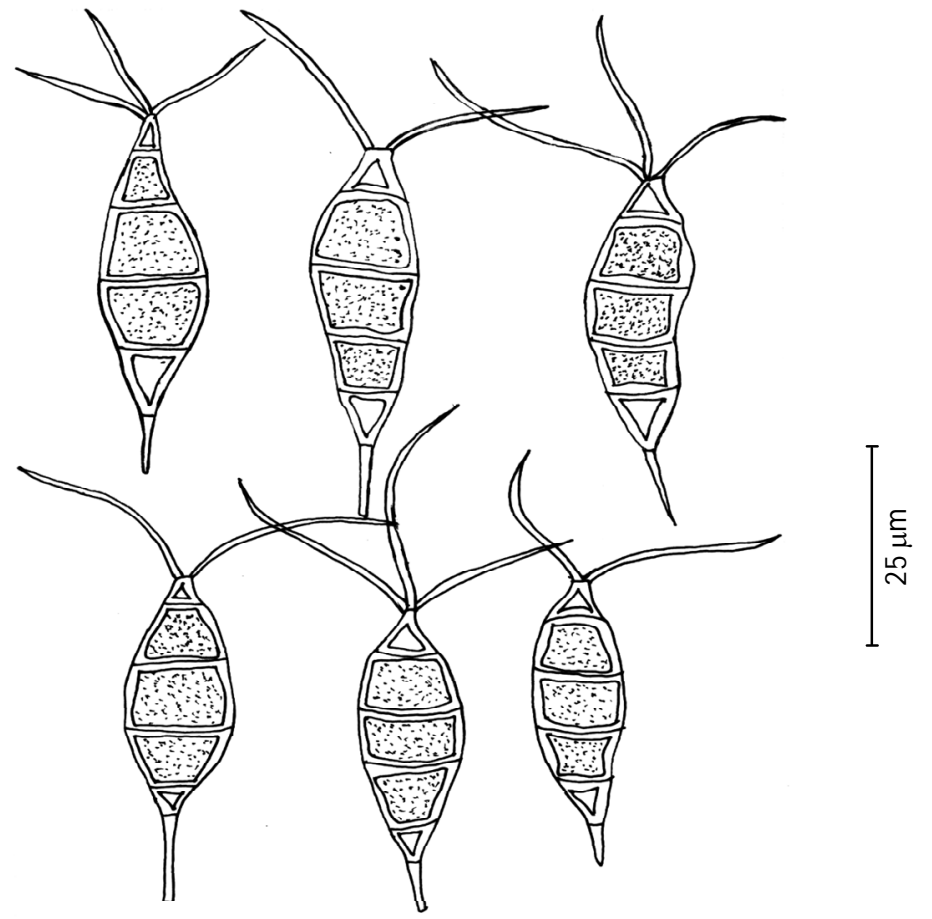

Fig. 2. Pestalotiopsis guepinii: Camera lucida drawing of conidia. 
The fungi were isolated from the samples following "Tissue planting method" on PDA (Potato Dextrose Agar) medium and "Blotter method" (CAB 1968). The diseased leaf samples were washed under flowing tap water. Then the leaves were cut into pieces $\left(2^{2} \mathrm{~mm}\right)$. Then cut pieces were sterilized in $10 \%$ Chlorox for 2 minutes and then washed in sterilized water thrice. After washing the cut pieces were placed on PDA medium in Petri plates at 3 pieces per plate for "Tissue planting method". Moist chamber was prepared by placing 3 layered moist blotting paper (Whatman No.1) in bottom part of Petri plates at 5 pieces per plate for "Blotter Method". Petri plates with inoculated wheat leaves were incubated for $5-7$ days at $20 \pm 2{ }^{\circ} \mathrm{C}$. Fungi grew from the diseased leaves were transferred to separate PDA plates and PDA slants for further studies and preservation. Then isolated fungi were identified based on morphological characteristics observed under a compound microscope following standard literatures (Barnet and Hunter 1972, Ellis 1971, 1976, Ellis and Ellis 1997, Sutton 1982). Prevalence (\%) of fungi in both the wheat varieties was also recorded.

Taxonomic enumeration of Pestalotiopsis guepinii (Desm.) Stay. Colonies white, cottony on PDA medium at $\mathrm{pH} 6.0$ and temperature $25 \pm 1^{\circ} \mathrm{C}$. Mycelia hyaline, septate, profusely branched, fruiting structure black, shining, conspicuous, condiomata $200 \mu \mathrm{m}$. Conidiophores short hyaline, 10 - $15 \times 1$ - $2 \mu \mathrm{m}$, mostly aseptate with 1 - 2 proliferation. Conidia blackish brown, mostly three septate with $2-5$ hyaline appendages at the apex and short hyaline appendage at the base, apical appendages 16 - $33 \mu \mathrm{m}$ long and basal appendage 4 - $12 \mu \mathrm{m}$ long.

Based on these morphological characteristics, the fungus was identified as Pestalotiopsis guepinii (Desm.) Stay.

So far, Pestalotiopsis guepinii was recorded on A. vera L. (Sutrodhor and Shamsi 2013), Rosa spp. (Shamsi and Ghosh 2015), Senna alata L. (Shamsi et al. 2013) and grains of Oryza sativa L. Chowdhury et al. (2015) from Bangladesh. Association of the fungus with wheat is a new record.

\section{REFERENCES}

Ahmed, H. U. 1986. Prevailing Wheat Diseases in Bangladesh. In: Anonymous (ed.), Third National Wheat Training Workshop. pp. 124-134. Wheat Research Centre, BARI, Joydebpur, Gazipur.

Alam, K. B., P. K. Malaker, M. A. Shaheed, M. U. Ahmed, F. Ahmed and M. S. Haque 1995. Yield loss assessment of wheat due to Bipolaris leaf blight in Bangladesh. Bangladesh J. Pl. Pathol. 11 (1\&2): 35-38.

Alam, K. B., M. A. Shaheed, A. U. Ahmed and P. K. Malaker 1993. Bipolaris leaf blight disease of wheat in Bangladesh. A paper presented at the BARI-CIMMYT Int. Conference on wheat in warm area, Rice Farming System. Wheat Research Centre, Dinajpur, February 13-15. 
Barnet, H. L. and B. B. Hunter. 1972. Illustrated Genera of Imperfecti Fungi. Burgess Publishing Company, U.S.A. Third Edition. pp. 241.

CAB (Commonwealth Agricultural Bureau) 1968. Plant Pathologist Pocket Book. $1^{\text {st }}$ edn. The Commonwealth Mycological Institute, England. pp. 267.

Chowdhury, P. S. Shamsi and M.A. Bashar. 2015. Grain spotting of rice caused by Pestalotiopsis guepinii (Desm.) Stay - A new record. Dhaka Univ. J. Biol. Sci. 24(1): 103-106.

Ellis, M. B. 1971. Dematiaceous hyphomycetes. Commonwealth Mycological Institute, England. pp. 608.

Ellis, M. B. 1976. Dematiaceous hyphomycetes. Commonwealth Mycological Institute, England. pp. 507.

Ellis, M. B. and J. P. Ellis 1997. Micro Fungi on Landplants. An Identification Handbook. The Commonwealth Mycological Institute, England. pp. 868.

Rashid, A. Q. M. B., B. P. Lahiri and T. Islam 1994. Effect of Bipolaris sorokiniana leaf blight on some yield components and seed quality of wheat. Bangladesh $J$. Agril. Sci. 21(1): 185-192.

Shamsi, S., P. Chowdhury and N. Naher. 2013. Mycoflora associated with the leaves of Senna alata (L.) Roxb. J. Bangladesh Acad. Sci. 37(2): 249-252.

Shamsi, S. and A. Ghosh. 2015. Pestalotiopsis guepinii (Desm.) Stay - A new pathogen of Black spot disease of rose in Bangladesh. Bangladesh J. Plant Pathol. 29(1\&2): 11-14.

Sutton, B. C. 1982. The Coelomycetes, Fungi Imperfecti with Pycnidia Acervuli and Stromata. Commonwealth Mycological Institute, Kew, Surrey, England. pp. 696.

Shutrodhar, A.R. and S. Shamsi. 2013. Anthracnose and leaf spot diseases of Aloe vera L. from Bangladesh. Dhaka Univ. J. Biol. Sci. 22(2): 103-108.

Talukdar, M. J. 1974. Plant diseases of Bangladesh. Bangladesh J. Agril. Res. 1(1): 61-86.

(Received revised manuscript on 24 February, 2016) 